produce, Gold Coast ; B. E. V. Parham (temporary assistant agricultural officer), agricultural officer, Fiji ; J. D. Tallantire (agricultural officer, Nigeria), agricultural officer, Gambia (seconded); H. E. Hornby (director of veterinary services), director of tsetse research, Tanganyika Territory; D. A. Donald (temporary assistant agricultural officer), agricultural officer, Fiji ; D. L. Foster (temporary assistant agricultural officer, Jamaica), junior agricultural instructor, British Honduras; L. W. Harwood (temporary assistant agricultural officer), agricultural officer, Fiji.

\section{Biology in Education}

UNDER the auspices of the Educational Advisory Board of the British Social Hygiene Council, a conference of principals and biology lecturers in training colleges will be held on October 22 at the British Medical Association House, Tavistock Square, London, W.C.1. Prof. J. B. S. Haldane will speak on "How to Make Biology Alive", and his remarks will be followed by discussion. Dr. Philippa Esdaile will speak on "The Place of Field and Practical Work in the Biology Course". A discussion on "The Concept of Human Biology" will be opened by Mrs. E. J. Hatfield and Dr. H. C. Squires. A selection of biological films will also be exhibited. Further information can be obtained from the Secretary, Educational Advisory Board, British Social Hygiene Council, Tavistock House South, Tavistock Square, London, W.C.1.

\section{Announcements}

Prof. B. W. Holman, assistant professor of mining in the Imperial College of Science and Technology, has been awarded the Gold Medal of the National Bureau of Scientific and Industrial Research by the French Minister of Instruction and Fine Arts. The award of this medal to a British subject is very unusual.

Dr. Albert E. Quine, a medical officer of the Ministry of Health, has been appointed inspector of anatomy in England and Wales.

Sir Henry Bashford, chief medical officer of the General Post Office, and Sir Kenneth Lee, chairman of Tootal Broadhurst Lee Co., Ltd., have been appointed to fill vacancies in the membership of the Industrial Health Research Board of the Medical Research Council.

The Council of the Iron and Steel Institute confirms that, in accordance with previous announcements, the joint Autumn Meeting of the Iron and Steel Institute and the Institute of Metals in New York and the tours in Canada and the United States of America have been cancelled. The Autumn Meeting of the Iron and Steel Institute will be held at the Institution of Civil Engineers, Great George Street, Westminster, S.W.1, on October 26 , at 10 a.m. and at 2.30 p.m. The Institute of
British Foundrymen has accepted an invitation for members to take part in the discussion on the third report of the Steel Castings Research Committee which will be presented during the afternoon session.

The Council of the Iron and Steel Institute has accepted an offer from Captain C. A. Ablett to present a prize of $£ 50$ for the best paper on steelworks engineering submitted to the Institute, written by a junior engineer employed in a British iron or steel works, irrespective of whether or not he is a member of the Institute. Competing papers should be marked "Ablett Prize Paper" and sent to the Secretary of the Iron and Steel Institute, No. 4 Grosvenor Gardens, London, S.W.1, not later than January 31. 1939.

The fifth biennial conference of the National Council of Mental Hygiene will be held at the Central Hall, Westminster, on January 12-14, 1939. Further information can be obtained from the Secretary of the Council, 76 Chandos Street, Palmer Street, London, S.W.1.

Applicatrons are invited for the Eunice Oakes research fellowship at the Hospital for Sick Children, Great Ormond Street, London, W.C.I. Candidates must be less than thirty-five years of age. The salary will not be less than $£ 750$ per annum. Further information can be had from the Secretary of the Hospital.

The Middlemore Prize for 1939 in medical and surgical ophthalmology, consisting of a cheque for $£ 50$ and an illuminated certificate, founded in 1880 by the late Mr. Richard Middlemore of Birmingham, is offered by the British Medical Association for the best essay on the underlying causes of glaucoma with suggestions as to future research in clinics and laboratories. The essay should be sent to the Secretary, B.M.A. House, Tavistock Square, London, W.C.1, before December 31, 1938.

THE Council of the Ophthalmological Society of the United Kingdom has established a Treacher Collins prize of $£ 100$ to be awarded triennially for the best essay submitted upon a subject selected by the Council. The subject for the first award is "Cerebrospinal Disease in Relation to the Optic Nerve". Essays should be sent before December 31, 1938, to the Hon. Secretary, Ophthalmological Society of the United Kingdom, 5 Racquet Court, Fleet Street, E.C.4.

IT has been decided to form a medico-historical museum in Berlin after the model of the Wellcome Museum in London.

AN unusually large number of cases of infantile paralysis in Holland this summer has caused German authorities in some districts to forbid Dutch children crossing the frontier. 